\title{
MODERN STRUCTURAL-DYNAMIC ORGANIZATION OF PHYTOCOENOSES AT ENVIRONMENTAL CONTACTS UNDER THE IMPACT OF ANTHROPOGENIC (FIRES, CUTTING, PASTURAGE) FACTORS (South-Western Trans-Baikal, Russia)
}

\author{
Alexander Sizykh ${ }^{1 *}$, Tatyana Konovalova ${ }^{2}$ \\ ${ }^{1 *}$ Siberian Institute of Plants Physiology and Biochemistry of RAS SB, 664033 Irkutsk, 132 Lermontova str., Russia; \\ ${ }^{2}$ V.B. Sochava Institute of Geography, Siberian Branch of Russian Academy of Sciences, \\ Irkutsk, 664033, 1 Ulan-Batorskay str., Russia: \\ *Corresponding Author Alexander Sizykh, e-mail: alexander.sizykh@gmail.com;
}

Received March 2021; Accepted April 2021; Published May 2021;

DOI: https://doi.org/10.31407/ijees11.307

\begin{abstract}
While performing studies within the grant (RFBR No 29-05-00253), we imposed the tasks to reveal general (background) characteristics of structural-dynamic organization of the vegetation and to find out the peculiarities of formation of phytocoenoses on the sites reflecting the specifics and trends of their modern formation under anthropogenic impact, such as fires, cutting and pasturage during several decades. The studied area is situated in the transitional zone between the forest-steppe and zonal steppes characteristic for South-East Asia - i.e., in an interzonal ecotone. An interzonal ecotone consists of coenoses forming under transitional environmental conditions, in this case - between forest-steppe and steppe areas of North and Central Asia. Main attention was paid to the characteristics of the actual state of phytocoenoses forming under different conditions of their recent destructions; species composition of synfolia and the most characteristic proxy species determining the actual state and the vector of formation of steppe coenoses and forests during last decades were studied with a particular attention. Certainly, while analyzing the data obtained, we took into account as well the characteristics of the vegetation structure in the studied area presented in published papers of numerous researchers for many years - M.A. Reshchikov (1958, 1961), E.Ts. Dambiev, B.B. Namzalov, S.A. Kholboeva (2006). The results of general studies of the Baikal Region vegetation were also taken into account.
\end{abstract}

Key words: vegetation, structural-dynamic phytocoenoses; fires, cutting, pasturage factors; South-Western TransBaikal. 